\title{
EXPERIMENTAL STUDY ON THE INJECTION CHARACTERISTICS OF HYDROTREATED VEGETABLE OIL IN A DIESEL ENGINE COMMON RAIL SYSTEM
}

\author{
VO TAN CHAU ${ }^{1}$, DUONG HOANG LONG ${ }^{2}$, CHINDA CHAROENPHONPHANICH $^{3}$ \\ ${ }^{1}$ Faculty of Automotive Engineering Technology, Industrial University of Ho Chi Minh City; \\ ${ }^{2}$ Faculty of Mechanical, Electrical, Electronic and Automotive Engineering, Nguyen Tat Thanh \\ University \\ ${ }^{3}$ Faculty of Engineering, King Mongkut's Institute of Technology Ladkrabang; \\ votanchau@iuh.edu.vn
}

\begin{abstract}
The diesel combustion is primarily controlled by the fuel injection process. The start of injection therefore has a significant effect in the engine, which relates large amount of injected fuel at the beginning of injection to produces a strong burst of combustion with a high local temperature and high $\mathrm{NO}_{\mathrm{x}}$ formation. This paper investigated the impact of Hydrotreated Vegetable Oil (HVO) and blends of 10\%, 20\%, 30\%, $50 \%, 80 \%$ by mass of HVO with commercial diesel fuel (mixed 7\% FAME-B7) to injection process under the Zeuch's method and compared to that of B7. The focus was on the injection flow rate in the variation of injection pressures, back pressures, and energizing times. The experimental results indicated that injection delay was inversely correlated to HVO fraction in the blend as well as injection pressure. At different injection pressures, HVO revealed a slightly lower injection rate than diesel that resulted in smaller injection quantity. Discharge coefficient was recognized larger with HVO and its blends. At $0.5 \mathrm{~ms}$ of energizing time, injection rate profile displayed the incompletely opening of needle. Insignificant difference in injection rate was observed as increasing of back pressure.
\end{abstract}

Keywords. Hydrotreated Vegetable Oil (HVO), Bulk Modulus of Compressibility, Injection Rate-Zeuch Method, Injection Characteristics, Common-Rail Injection System.

\section{INTRODUCTION}

Diesel engine emissions have been contributing to environmental pollution, especially $\mathrm{NO}_{\mathrm{x}}$ and particulate matter (PM). To satisfy the increasing of emission standards being applied on many countries, the reducing diesel engine emissions is currently being considered as a top priority in the researches of diesel engine. As known, fuel injection process is the first important influence on the sequence of atomization, spray evolution, air-fuel mixing, and hence the engine performance along with its pollutant emissions. The control of fuel mass flow rate is not only heat release rate in combustion to achieve the desired smooth running but also the trade-off between soot and $\mathrm{NO}_{\mathrm{x}}$ through precisely controll of injection rate shape to provide high accurate as possible fuel mass per work cycle. On this aspect, Payri et al. 0, built a model that can quickly simulate mass flow rate for many operation points and calculate the injected mass using few inputs such rail pressure, back pressure, energizing time, etc. Error from the model showed within 5\% compared with realistic experiment. With the flexibility of the common rail system in modern diesel engine, study on the effect of the parameters of common rail system on the injection rate under Bosch long tube method was conducted by $\mathrm{Yu}$ et al. [2]. This research concluded that the primary parameters including injection pressure, electronic control signal (drive voltage, injection pulse) had significant effect on injection rate. This is consistent with other researches by Mulemane et al. [3], Henein et al. [4], Several studies on injection rate used Zeuch's method, for instance, Lucio's research [5] with advanced injection strategies using common-rail system, provided a proper definition of actual injection start by the first positive values of the injected volume; Ishikawa et al. [6] studied multiple injection in CDI (Common rail-direct injection) diesel engine. This paper pointed out the advantage of Zeuch's method which was employed on the developed injection rate meter on the aspects of high accurate detection of small injected fuel quantity and sharper detection of injection termination during injection process. In the effort in further improving particulate matter (PM) and $\mathrm{NO}_{\mathrm{x}}$ emissions by exact controlling injection rate according to engine conditions (speed, load, swirl ratio, pulse timing and duration), Hwang et al. [7] investigated the effect of fuel injection rate on the pollutant emissions in DI diesel engine and concluded that there are the optimum injection rates 
according to engine speed and load; other research by Nishimura et al. [8] reported that the optimal amount of fuel injected in initial injection rate and controlling injection pressure have great reduction of $\mathrm{NO}_{\mathrm{x}}$ emission and combustion noise. Interestingly, these findings are consistent with the experiments on the heavy/medium duty DI-diesel engine with varying the injection rate patterns to compare combustion, emissions and fuel consumption by Tanabe et al. [9] and Benajes et al. [10]. The notable results presented a significant influence on $\mathrm{NO}_{\mathrm{x}}$, soot emissions concerning directly from the change in the premixed and diffusion combustion.

Besides the accurate control of the injected fuel amount to get low exhaust emissions, smooth operation, and minimum fuel consumption, other researchers have demonstrated the use of alternative fuel which promises to reduce engine emissions. Recently, a combination of use in oxygenated fuel and optimum injection rate has been well described by Tinprabath et al. [11]. This research examined injection flow characteristics with mixing ratios of $10 \%, 20 \%, 30 \%, 40 \%, 50 \%$ biodiesel blended with diesel, and pure biodiesel originating rapeseed. The result presented that the different fuel properties such higher in viscosity and density of biodiesel caused a decrease of discharge coefficient at low injection pressure. A further study on the effect in the wide variation range of viscosity and density to injection rate was done by Dernotte et al. [12] and showed that high viscosity induced a decrease up to $10 \%$ in discharge coefficient at low injection pressure difference but interestingly, at high pressure difference, fuel density remained the only fuel property driving the mass flow rate. It is noted that the larger in viscosity of biodiesel causes higher flow friction loss and greater Sauter Mean Diameter (SMD) which make mass flow rate reduction (Bang et al. [13], Seykens et al. [14], Som et al. [15], Desantes et al. [16], Dong Han et al. [17]). In addition, with the high in cloud point and pour point, biodiesel flow characteristics in cold condition are also described by Tinprabath et al. [18] and showed that the discharge coefficient for all test fuels are lower than at room temperature and only a change in viscosity or density can impact on the flow rate. It is well-known that cavitation phenomenon strongly affected on injection process, under occurrence of cavitation, discharge coefficient suddenly drops which accompanies the collapse of the mass flow rate, an increase in the spray angle and velocity outlet. These tendencies appear in all experiments and have been observed by other researchers (Desantes et al. [19], Payri et al. [20], Benajes et al. [21], Payri et al. [22], Badock et al. [23]). From above point of views, it is necessary to know the physical properties of injection characteristics of biofuels base diesel fuel inside the injector in order to improve the characteristics of biofuel, injector geometry, injection strategy, engine chamber and thus achieve the highest engine efficiency. However, studies on injection dynamics flow for HVO is very limited. This study was carried out to reach a new understanding of injection rate behaviors of HVO, the relationship between discharge coefficient and the percentage of $\mathrm{HVO}$ in the blends, and the relationship between discharge coefficient and injection pressure, back pressure, injection length command.

\section{INJECTION RATE-ZEUCH METHOD}

In this study mainly focused on the injection characteristics which consist of injection rate, injection delay, discharge coefficient, injection quantity, and others relevant quantities. By Zeuch's method [24], the fuel injection characteristics were performed. The tested fuel was injected into constant volume chamber filled full with the same tested fuel at a certain pressure (back pressure). At the time of injection occurred, the pressure in chamber increased in proportion corresponding with the injected fuel quantity. By using the fuel bulk modulus of compressibility $(\mathrm{K})$ derived from pressure rise $(\Delta \mathrm{P})$ according to equation $(1)$, the equation of injection rate $(\mathrm{dm} / \mathrm{dt})$ is formed based on the conservation of mass as shown in equation (2):

$$
\begin{aligned}
& \mathrm{K}=\mathrm{V} \frac{\Delta \mathrm{P}}{\Delta \mathrm{V}} \\
& \dot{m}_{\text {measured }}=\frac{d m}{d t}=\rho_{f} \frac{V}{K} \frac{d P}{d t}
\end{aligned}
$$




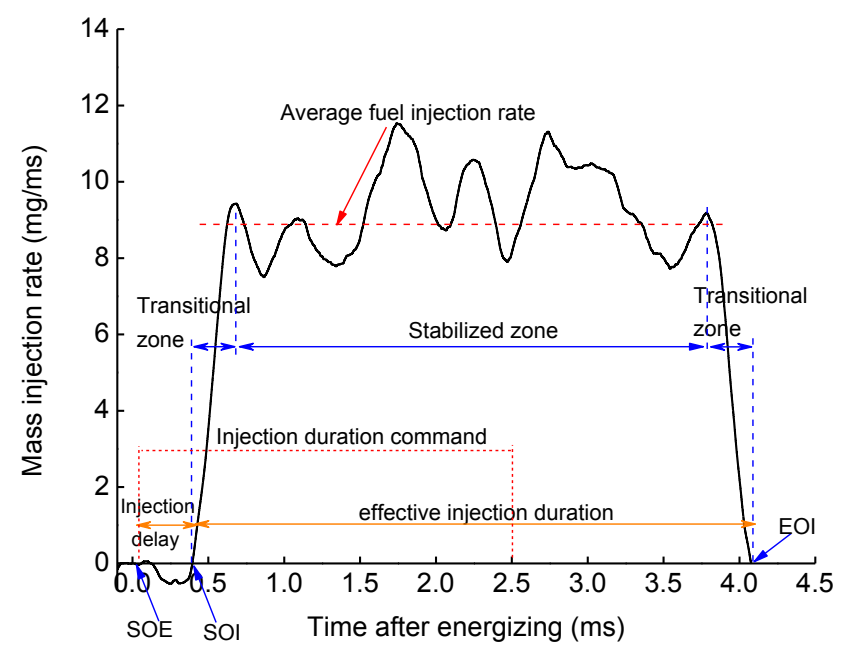

Figure 1: Definition of typical fuel injection rate $\left(\mathrm{B} 7, \mathrm{P}_{\mathrm{inj}}=80 \mathrm{MPa}, \mathrm{P}_{\mathrm{b}}=4 \mathrm{MPa}, 2.5 \mathrm{~ms}\right.$ energizing

Injection rate profile obtained by equation (2) is displayed in figure 1. From this figure, it can be divided into 3 phases: injection delay, transitional zones (needle opening and needle closing), and stabilized zone (fully opening needle). The injection delay refers to the starting point of energizing (SOE) to starting point of injection (SOI) in which the curve initially changes from negative value to zero and positive value (Postrioti et al. [5], Dong Han et al. [17], Munsin et al. [25]). The effective injection duration was counted from SOI until end of injection (EOI). The quasi-steady state period of $1.5 \mathrm{~ms}$ to $3.5 \mathrm{~ms}$ after starting of energizing time was used to calculate the average injection rate and discharge coefficient $\left(\mathrm{C}_{\mathrm{d}}\right)$. Based on Dernotte's work [12], discharge coefficient is defined as a ratio between the measured mass flow rate

$\left(\mathrm{m}_{\text {measured }}\right)$ and theoretical mass flow rate ( $\mathrm{m}_{\text {theoretical }}$ ) derived from the combination of the continuity equation and Bernoulli equation as shown in equation (3) and equation (4):

$$
\begin{aligned}
& \mathrm{C}_{\mathrm{d}}=\frac{\mathrm{m}_{\text {measured }}^{\cdot}}{\mathrm{m}_{\text {theory }}^{*}} \\
& \mathrm{~m}_{\text {theory }}=\mathrm{n}_{\text {orifice }} \cdot A \cdot \sqrt{2 \Delta \mathrm{P} \cdot \rho_{\mathrm{f}}}
\end{aligned}
$$

The average velocity $\left(\mathrm{V}_{\text {average }}\right)$ was used to calculate Reynolds number $(\mathrm{Re})$ as shown in equation (5) and equation (6) (Tinprabath et al. [18]):

$$
\begin{aligned}
& \mathrm{V}_{\text {average }}=\frac{\mathrm{m}_{\text {measured }}^{\cdot}}{\mathrm{n}_{\text {Orifice }} \cdot A \cdot \rho_{\mathrm{f}}} \\
& \mathrm{Re}=\frac{\mathrm{V}_{\text {average }} \cdot \mathrm{D}_{\text {inj }}}{v}
\end{aligned}
$$

\section{EXPERIMENTAL SET-UP AND TEST CONDITIONS}

\subsection{Test Fuels}

Seven types of fuel chosen in this research are commercial diesel fuel at Thailand (B7-blended 7\% Palm Methyl-ester) as a reference fuel, neat Hydrotreated Vegetable Oil (HVO) and blends of HVO in ratios of $10 \%, 20 \%, 30 \%, 50 \%$, and $80 \%$ by mass with diesel fuel. All fuels were supplied by Thailand's PTT 
Table 1: Fuel properties

\begin{tabular}{|l|c|c|c|c|c|c|c|c|c|}
\hline Fuel analysis & Standard & $\begin{array}{c}\text { Diesel fuel } \\
\text { (B7) }\end{array}$ & $\mathrm{H} 10$ & $\mathrm{H} 20$ & $\mathrm{H} 30$ & $\mathrm{H} 50$ & $\mathrm{H} 80$ & & $\begin{array}{c}\text { Neat } \\
\text { HVO }\end{array}$ \\
\hline $\begin{array}{l}\text { Viscosity } \\
@ 40^{\circ} \mathrm{C}(\mathrm{cSt})\end{array}$ & $\begin{array}{c}\text { ASTM } \\
\text { D445 }\end{array}$ & 3.235 & 3.126 & 3.088 & 2.960 & 2.901 & 2.740 & & 2.637 \\
\hline $\begin{array}{l}\text { Density } \\
\left(\mathrm{Kg} / \mathrm{m}^{3}\right)\end{array}$ & $\begin{array}{c}\text { ASTM } \\
\text { D4052 }\end{array}$ & 823.5 & 818.8 & 814 & 807.5 & 799.9 & 786.5 & & 778 \\
\hline $\begin{array}{l}\text { Surface } \\
\text { tension } \\
(\mathrm{mN} / \mathrm{m})\end{array}$ & $\begin{array}{c}\text { ASTM } \\
\text { D1590 }\end{array}$ & 26.38 & 26.09 & 25.89 & 25.76 & 25.56 & 24.91 & & 24.84 \\
\hline Formula & $\begin{array}{c}\text { Master } \\
3625\end{array}$ & $\mathrm{C}_{14.28} \mathrm{H}_{26.43}$ & & $\mathrm{C}_{14.23} \mathrm{H}_{27.17}$ & & $\mathrm{C}_{14.09} \mathrm{H}_{29.36}$ & $\mathrm{C}_{14.09} \mathrm{H}_{29.36}$ & & $\mathrm{C}_{14.03} \mathrm{H}_{30.1}$ \\
\hline
\end{tabular}

Research and Technology Institute. Fuel properties are listed in table 1. Because the fluid characteristics involved during the injection process are somewhat different than the parameters which affect the combustion. Therefore, some of the fuel properties which will be used for analyzing in this part are presented.

The lower viscosity of HVO than B7 of about $18.48 \%$ is caused by shorter chain length and paraffinic fuel. In addition, commercial diesel fuel with $7 \%$ palm methyl-ester contributes higher viscosity due to the presence of unsaturated compounds (Soo-Young No [26]). The lower viscosity results in less friction flow, thus less deposit formation and more accurate operation in injector. It also results in better atomization, smaller droplet size and wider angle of fuel spray in engine combustion (Borhanipour et al. [27], Pandey et al. [28]). Similarly, density of HVO is $5.52 \%$ less than B7 due to the fact that it is basically a mixture of nparaffinic and iso-paraffinic, with lower chain length and smaller molecular weight (Soo-Young No [26], Lapuerta et al. [29]). This causes, not only the influence in delivery of fuel mass to the combustion chamber due to looser particles in the packs of substance, but also retarded injection timing which contributes to lower temperature combustion (Pandey et al. [28]). In regard to surface tension, HVO has 5.84\% less than diesel. As expected, this property will be useful in spray atomization.

\subsection{Experimental Set-up and Test Conditions}

The schematic of experimental setup is described in figure 2. A single-hole solenoid diesel injector with diameter of $0.2 \mathrm{~mm}$ was installed on the top of the Zeuch chamber with the capacity of $40 \mathrm{~cm}^{3}$. To determine injection rate, the tested fuel was fully filled into the chamber by hydraulic hand pump until it reached the desired back pressure, i.e. $4 \mathrm{MPa}$, measured by a static pressure sensor. Then, the tested fuel was injected by the common rail injection system which driven by a three phases electric motor through an inverter, resulting in a steep pressure rise in chamber measured by a piezoelectric pressure transducer sensor. Then, this pressure signal was transmitted to charge amplifier and recorded by oscilloscope with real time synchronously. The injection duration and trigger time were controlled by a programmable microcontroller that is actuated by the Electric Drive Unit (EDU) to inject fuel into the Zeuch chamber.

To measure fuel bulk modulus, high pressure of nitrogen $\left(\mathrm{N}_{2}\right)$ gas connected with pneumatic cylinder which used to push plunger located with a dial gauge to measure the displacement of plunger. The movement of the plunger into the chamber caused the reduction of volume chamber lead to increase pressure. By using equation (1), the bulk modulus of fuel was determined and used as a calibrating factor for injection rate calculation. Experiments were carried out at room temperature $301 \mathrm{~K} \pm 2 \mathrm{~K}$. 


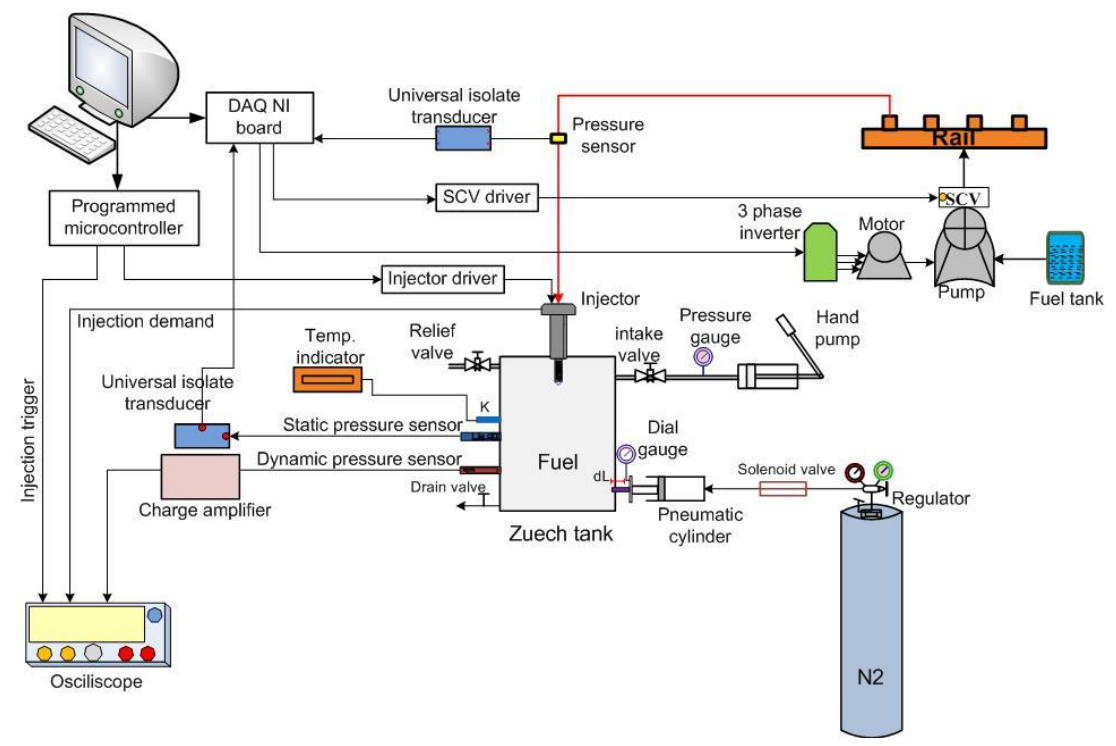

Figure 2: Schematic arrangement of experimental apparatus

Table 2: Experimental conditions

\begin{tabular}{|l|c|}
\hline \multicolumn{1}{|c|}{ Fuels } & $\mathrm{B} 7, \mathrm{H} 10, \mathrm{H} 20, \mathrm{H} 30, \mathrm{H} 50, \mathrm{H} 80, \mathrm{HVO}$ \\
\hline Back pressure $\left(\mathrm{P}_{\mathrm{b}}\right)$ & $2 \mathrm{MPa}, 4 \mathrm{MPa}, 6 \mathrm{MPa}$ \\
\hline Rail pressure $\left(\mathrm{P}_{\mathrm{inj}}\right)$ & $40 \mathrm{MPa}, 60 \mathrm{MPa}, 80 \mathrm{MPa}, 100 \mathrm{MPa}, 120 \mathrm{MPa}$ \\
\hline Nozzle type & Solenoid, single hole \\
\hline Hole diameter & $0.2 \mathrm{~mm}$ \\
\hline Injection command & $0.5 \mathrm{~ms} ; 1.0 \mathrm{~ms} ; 1.5 \mathrm{~ms} ; 2.0 \mathrm{~ms} ; 2.5 \mathrm{~ms}$ \\
\hline
\end{tabular}

Table 2 shows the experimental test conditions. Fuel blends were carried out only at 4.0MPa of back pressure, $2.5 \mathrm{~ms}$ of energizing time and various injection pressures. The comparison between HVO and diesel was conducted at various energizing times, injection pressures, and back pressures.

\section{RESULT AND DISCUSSION}

\subsection{Fuel Bulk Modulus of Compressibility}

Bulk modulus of compressibility implies the resistance of liquid to uniform compressibility. Figure 3 shows the relationship between bulk modulus of HVO fraction in blend and various back pressures. From this figure, the bulk modulus proportionally increased with decreased of $\mathrm{HVO}$ fraction in blend. This is due to the impact of molecular structure of diesel fuel such as unsaturated component (mixed with 7\% FAME), aromatic composition, cycloalkane, branched alkane, etc. caused more difficulty in com-pressing fuel in the same volume chamber than straight chain length structure as explained by Lapuerta et al. [29], An-dré et al. [30].

In addition, at applied higher back pressure, the compressibility of liquid is lower owing to the tightly packed molecules as well as the compression of the molecules themselves causes opposite among intermolecular repulsion. This leads to the linear increase of bulk modulus as increasing back pressure. HVO has smaller bulk modulus than diesel fuel around $7.57 \%$ for all back pressures. The difference in fuel bulk modulus will directly affect to engine injection timing that thus to shift in the combustion timing and $\mathrm{NO}_{\mathrm{x}}$ emission formation (André et al. [30], Heywood [31]). 


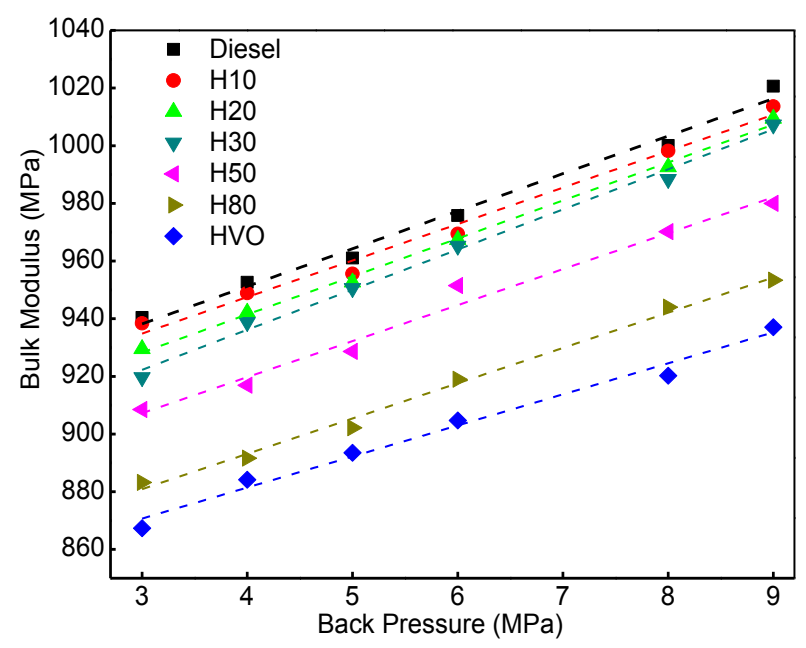

Figure 3: Effect of HVO fraction (by mass) on fuel bulk modulus of compressibility

\subsection{Hydraulic Injection Delay}

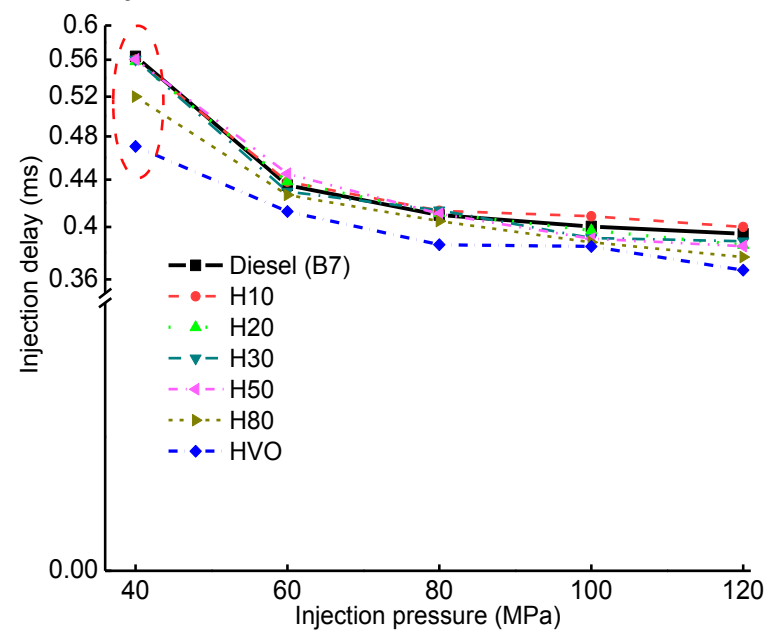

Figure 4: Hydraulic injection delay of all test fuels under $t=2.5 \mathrm{~ms}$ and $\mathrm{P}_{\mathrm{b}}=4.0 \mathrm{MPa}$

Figure 4 shows the hydraulic injection delay of all tested fuels at 4.0MPa of back pressure, $2.5 \mathrm{~ms}$ of energizing time with injection pressures in range of $40 \mathrm{MPa}$ to $120 \mathrm{MPa}$. All the injection delay data lie in range of $0.36 \mathrm{~ms}$ to $0.56 \mathrm{~ms}$. It is clearly observed that $\mathrm{HVO}$ and blends have earlier injection timing than B7 under same start of energizing time and injection pressure due to smaller viscosity results in lower resistance force for needle lift and faster fuel flow out of control chamber immediately after solenoid valve opening. From this figure, diesel and blends of HVO with the mixed ratio up to $50 \%$ display the insignificant difference of the hydraulic injection delay. As reported, higher bulk modulus leads to earlier injection timing with in-line pump-line nozzle fuel injection system but in the common rail system, the injection pressure is constantly maintained at the desired injection pressure, the fuel flows through the orifice at a timing controlled electro-mechanically. Therefore, the influence of the bulk modulus is expected negligibility in the opening needle timing. These observations are consistent with other findings (Dong Han et al. [17], Andre et al. [30]). Furthermore, the hydraulic injection delay shows a downward trend as increasing of injection pressure. This can be explained by pressure differential between the controlled volume of injector and at exit orifice which leads to faster needle lift (Dong Han et al. [17], Henein et al. [32]). 


\subsection{The Effective Injection Duration}

Effective injection duration counted from SOI until EOI is displayed in figure 5. According to this figure, effective injection duration is prolonged as compared to the current command duration of $2.5 \mathrm{~ms}$. This depends on the rate of opening and closing needle, needle lift during fuel delivery, nozzle type and fuel properties (Henein et al. [32]). This figure also shows a reducing trend of the effective injection duration (earlier closing) as increasing injection pressure due to reducing the effect of viscosity so as to descend the resistance of needle closure process. Therefore, increased fuel injection pressure difference enhances to lift and close needle more rapidly. Also, the effective injection duration is hardly affected by HVO fraction in blends. This may be caused by the compensative effect between the low bulk modulus of HVO fraction which has slow impact of fuel pressure on needle movement at needle closure timing and small viscosity with less friction.

\subsection{The Averaged Value of Mass Flow Rate}

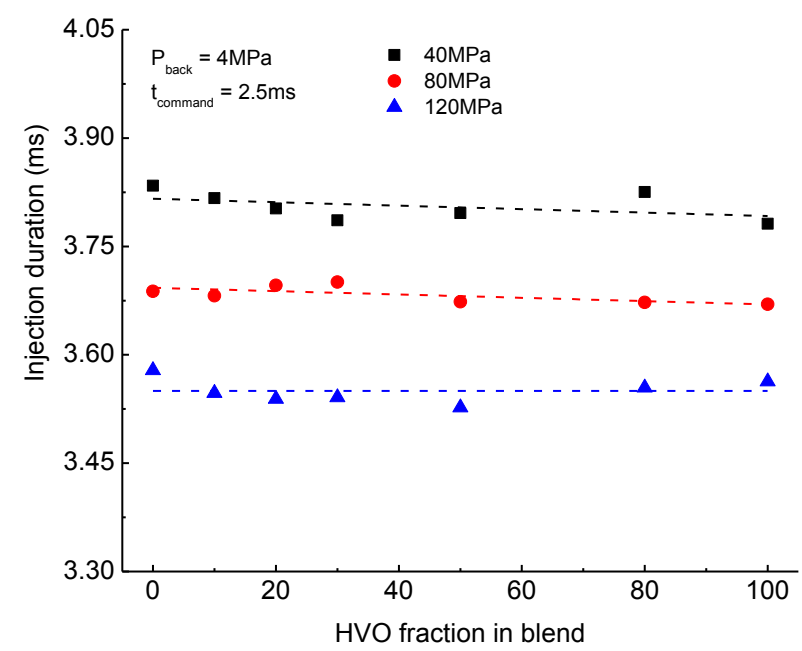

Figure 5: Effective injection duration of all test fuels at $2.5 \mathrm{~ms}$ of energizing time, $\mathrm{P}_{\mathrm{b}}=4.0 \mathrm{MPa}$

Mean mass flow rate during quasi-steady state period calculated from $1.5 \mathrm{~ms}$ to $3.5 \mathrm{~ms}$ with various injection pressures was displayed in figure 6 . Slightly higher mean injection rate of diesel is attributed by larger inertial fore from higher density (Dernotte et al. [12], Desantes et al. [16]). HVO with lower injection rate may cause the shorter in spray penetration and air-fuel interaction in surrounding environment of chamber. HVO and blends had insignificantly difference in mean mass flow rate. In addition, injection rate increases when increasing injection pressure owing to higher flow capacity (Dong Han et al. [17], Henein et al. [32]).

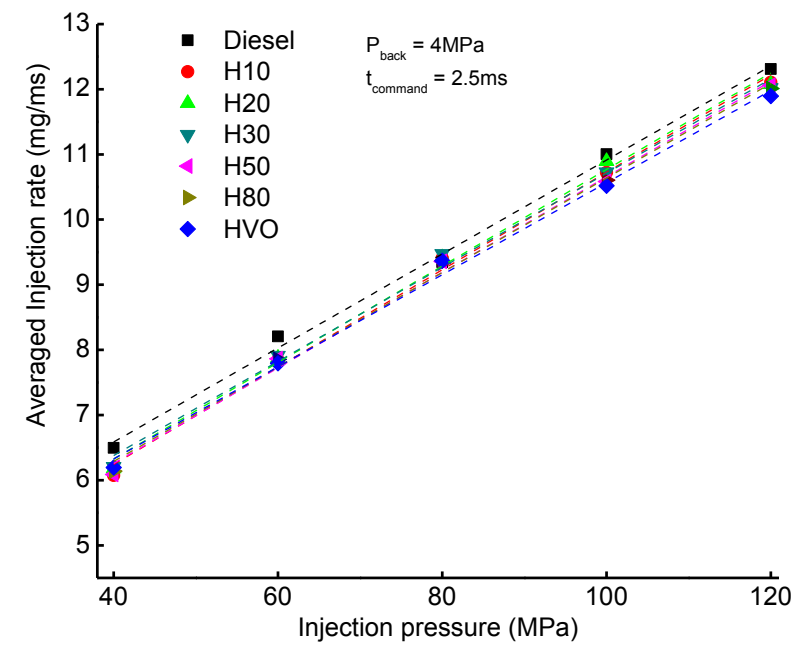

Figure 6: Mean injection rate of all fuels at stable injection period of $1.5 \mathrm{~ms}-3.5 \mathrm{~ms}$. 
The mass flow rate for various energizing times of diesel and HVO under 120MPa of injection pressure can be seen in figure 7 as representative. The results of mass injection rate under $0.5 \mathrm{~ms}$ of energizing time for both fuels show the extreme short in steady phase of injection process due to incompletely needle opening. For each fuel, the change in energizing time from $0.5 \mathrm{~ms}$ to $2.5 \mathrm{~ms}$ produces the insignificant difference in the hydraulic injection delay as well as the averaged value of mass flow rate after fully opening needle. Besides, longer energizing time of $0.5 \mathrm{~ms}, 1.0 \mathrm{~ms}, 1.5 \mathrm{~ms}, 2.0 \mathrm{~ms}$, and $2.5 \mathrm{~ms}$ produces longer effective injection duration corresponding $0.864 \mathrm{~ms}, 1.959 \mathrm{~ms}, 2.574 \mathrm{~ms}, 3.027 \mathrm{~ms}, 3.612 \mathrm{~ms}$ for diesel and $0.880 \mathrm{~ms}$, $1.949 \mathrm{~ms}, 2.574 \mathrm{~ms}, 3.031 \mathrm{~ms}, 3.571 \mathrm{~ms}$ for HVO. Furthermore, HVO's falling slopes show slight earlier closure than B7 at each condition. It is possibly due to its lower viscosity which causes fast-down the needle process.

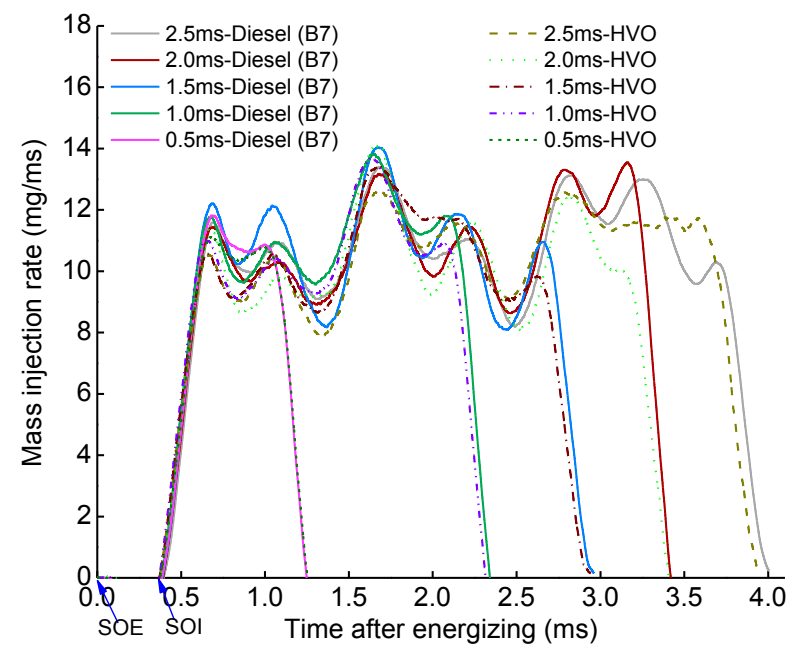

Figure 7: Mass injection rates of diesel and $\mathrm{HVO}$ at $\mathrm{P}_{\text {inj }}=120 \mathrm{MPa}, \mathrm{P}_{\mathrm{b}}=4 \mathrm{MPa}$ and various injection durations $(0.5 \mathrm{~ms}, 1.0 \mathrm{~ms}, 1.5 \mathrm{~ms}, 2.0 \mathrm{~ms}, 2.5 \mathrm{~ms})$

Figure 8 presents the impact of back pressure on the averaged injection rate between HVO and diesel. According to this figure, there is no significantly difference in injection rate when varying back pressures in range from 2.0MPa to 6.0MPa.

\subsection{The Fuel Injection Quantity}

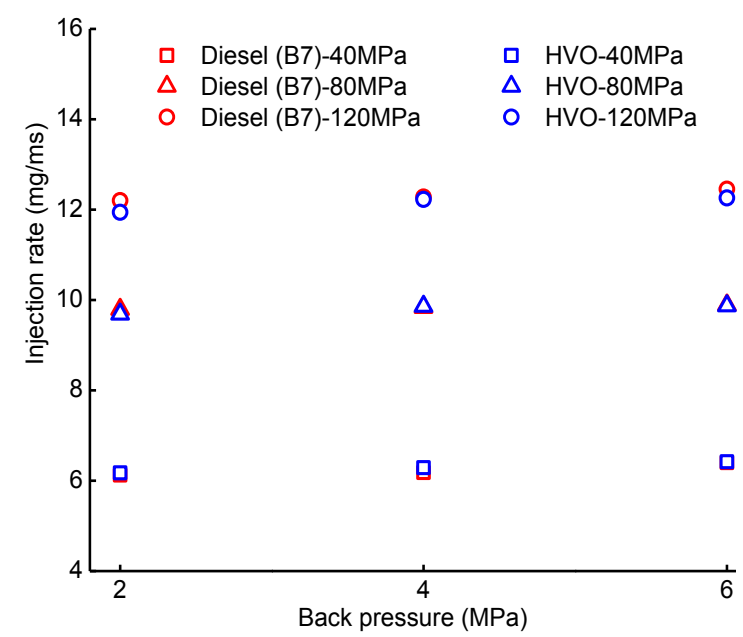

Figure 8: Mean injection rate of diesel and $\mathrm{HVO}$ at $2.5 \mathrm{~ms}$, different $\mathrm{P}_{\text {inj }}$, and $\mathrm{P}_{\mathrm{b}}$

Fuel injection quantity at different injection pressures for all fuels under 4.0MPa of back pressure, $2.5 \mathrm{~ms}$ of energizing time is calculated from integration of injection rate curves by Simpson's rule and depicted in figure 9. Diesel has higher injection quantity than HVO and blends due to higher density (Dernotte et al. 
[12], Desantes et al. [16]). More specifically, diesel fuel approximately increases $5.85 \%$ the injected fuel amount at all injection pressures compared to neat HVO, averagely.

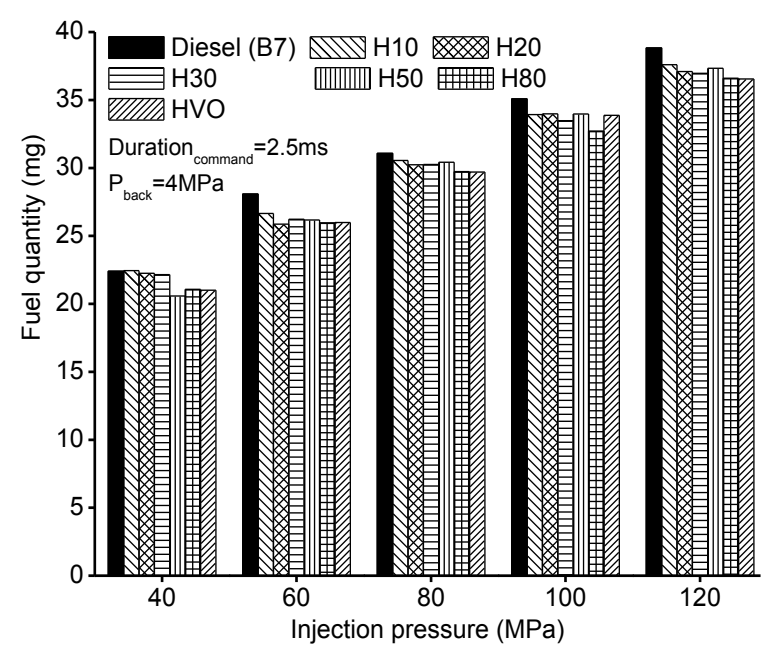

Figure 9: Mean injection rate of all fuels at stable injection period of $1.5 \mathrm{~ms}-3.5 \mathrm{~ms}$.

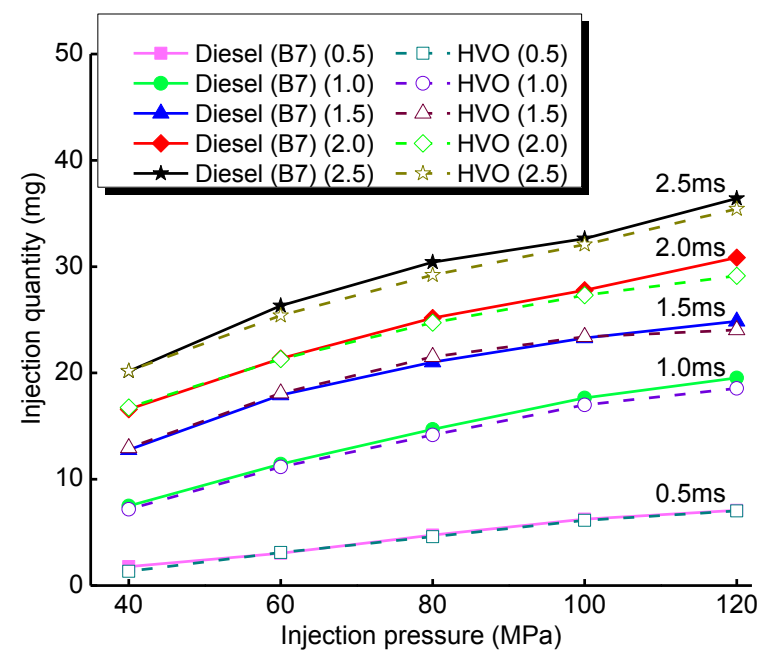

Figure 10: Injection quantity of $\mathrm{HVO}$ and diesel at $\mathrm{P}_{\mathrm{b}}=4 \mathrm{MPa}$, various injection durations and injection pressures.

Figure 10 shows the injection quantity of all injection pressures from $40 \mathrm{MPa}$ to $120 \mathrm{MPa}$ with various energizing times between HVO and diesel. Generally, diesel has higher the injection quantity than HVO for all energizing times and injection pressure as same propensity with figure 9. Also, from this graph, with increased injection pressure, injection quantity increases due to enhancing the flow capacity. It is noted that the distance of injection quantity line between $0.5 \mathrm{~ms}$ and $1.0 \mathrm{~ms}$ energizing time is larger than the others. It can be explained by partial opening needle at $0.5 \mathrm{~ms}$. On this viewpoint, the needle lift in multiple injection strategy of HVO will be affected by dwell-time and then injection timing, injection quantity.

\subsection{The Discharge Coefficient}

Discharge coefficient analyzed according to equation (3) is plotted versus with different injection pressures in figure 11a. From this figure, HVO and its blends have higher discharge coefficient than diesel as the effect of smaller viscosity and density makes lower friction loss. An approximate higher of $8.7 \%, 5.1 \%$, $3.2 \%, 3.2 \%, 2.5 \%$ of discharge coefficient corresponding with 40MPa, $60 \mathrm{MPa}, 80 \mathrm{MPa}, 100 \mathrm{MPa}, 120$ MPa of injection pressure is recognized with HVO, compared to diesel fuel. In addition, an increasing trend of discharge coefficient is observed with higher injection pressure in the studied injection pressure range. This is because the higher injection pressure reduces the influence of viscosity which leads to lower pressure loss. This result has similar propensity with other researches (Tinprabath et al. [11], Dernotte et al. [12], Benajes et al. [21], and Boudy et al. [33]). Cavitation phenomenon in injector represented by Reynolds 
number (Re) and cavitation number strongly impacts to discharge coefficient. According to Desantes's work [19], critical cavitation appearing in orifice injector will result in the decrease of discharge coefficient due to vapor formation in the outlet section of nozzle hole. From figure $11 \mathrm{~b}$, it is observed that there is no critical cavitation in the studied range of injection pressure. In this condition, discharge coefficient only depends on Re. From left side to right side of Re number axis in figure 11b, the increase of Re causes the increase of flow out effective velocity, higher turbulent level results in higher discharge coefficient. Furthermore, the increase of HVO fraction in blends produces higher Re number due to smaller viscosity. This will be attributed that HVO and its blends will be better in mixture formation.

Figure 12a shows the discharge coefficient for various energizing times at different injection pressures. Under low injection pressure and energizing time from $0.5 \mathrm{~ms}$ to $1.0 \mathrm{~ms}$, it is clearly seen the incompletely needle opening causes low discharge coefficient and after that as increased energizing time causes slightly higher discharge coefficient due to less pressure loss and fully needle opening. Figure 12b displays the impact of back pressure to discharge coefficient. Increasing trend of discharge coefficient is observed with higher back pressure at a constant injection pressure. It is attributed by the smaller pressure differential which causes smaller pressure loss.

\section{CONCLUSION}

This study was carried out to reach a new understanding of injection rate behaviors of $\mathrm{HVO}$, the relationship between discharge coefficient and the percentage of HVO in the blends, the relationship between discharge coefficient and injection pressure, back pressure, energizing time. Some conclusions are summarized as follows:

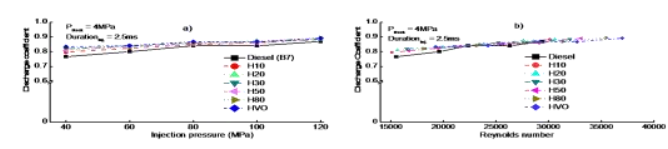

Figure 11: Discharge coefficient versus injection pressure (a) and discharge coefficient versus Reynolds number for all test fuels at $4 \mathrm{MPa}$ back pressure and $2.5 \mathrm{~ms}$ energizing time.

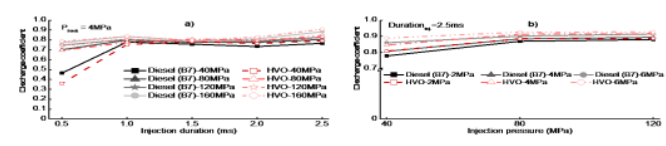

Figure 12: The impact of different injection durations to discharge coefficient at 4MPa back pressure (a) and the impact of various back pressures to discharge coefficient at $2.5 \mathrm{~ms}$ energizing time (b).

(1) HVO, its blends and B7 have similar to injection characteristics. Because molecular structure of B7 contains such unsaturated component, aromatic composition, cycloalkane, branched alkane which causes larger bulk modulus than HVO and blends. The bulk modulus proportionally increases with the decrease of HVO fraction in the mixture as well as linearly increases with higher back pressure. Neat HVO has 
smaller bulk modulus than B7 around $7.57 \%$ for all back pressures.

(2) Earlier injection timing is observed with $\mathrm{HVO}$ and its blends due to mainly smaller viscosity. Mixing ratio of $\mathrm{HVO}$ over $80 \%$ in blend shows clear difference of hydraulic injection delay as compared to B7.

(3) Longer effective injection duration compared to energizing times is obtained with all fuels. A reducing trend of the effective injection duration (earlier closing) is found as increasing injection pressure. The effective injection duration is hardly affected by HVO fraction in blends.

(4) Slightly higher mean mass flow rate was observed with diesel. This difference is mainly due to higher density of diesel. Higher mass flow rate is also recorded as increasing injection pressure for all fuels. This is caused by the increase of flow capacity. In addition, there is negligible change for both fuels in the averaged value of injection rate at the same injection pressure with various back pressures and energizing times.

(5) Diesel has higher injection quantity than HVO and blends owing to larger density. The difference in injection fuel quantity at the same injection pressure for both fuels will cause the different energy input that influences to engine performance. However, $\mathrm{HVO}$ and blends have higher discharge coefficient because of lower friction loss from smaller viscosity. An increasing trend of discharge coefficient is exhibited as increasing injection pressure.

(6) Critical cavitation condition is not found in the studied range of injection pressure, and discharge coefficient of nozzle increases with higher injection pressure corresponding linearly Re.

\section{ACKNOWLEDGMENT}

This work is supported by King Mongkut's Institute of Technology Lakrabang Research Fund (Grant No. KREF125615)-Thailand, AUN/SEED-Net program under Japan International Cooperation Agency (JICA). The authors would like to thank National Science and Technology Development Agency (NSTDA) and PTT Research \& Technology Institute for their contribution in this work.

\section{REFERENCES}

[1] R. Payri, J. Gimeno, R. Novella, G. Bracho, On the rate of injection modeling applied to direct injection compression ignition engines, International journal of engine research, 2016, doi: 10.1177/1468087416636281.

[2] G. Yu, L. Li, J. Deng, Z. Zhang, L. Yu, Research on the Effect of the Parameters of Common-Rail System on the Injection Rate, SAE-China, FISITA (eds) Proceedings of the FISITA 2012 World Automotive Congress, doi: 10.1007/978-3-642-33841-0_30

[3] A. Mulemane, J. Han, P. Lu, S. Yoon, M. Lai, Modeling Dynamic Behavior of Diesel Fuel Injection Systems, SAE Technical Paper 2004-01-0536, 2004, doi:10.4271/2004-01-0536.

[4] N. Henein, M. Lai, I. Singh, L. Zhong, J. Han, Characteristics of a Common Rail Diesel Injection System under Pilot and Post Injection Modes, SAE Technical Paper 2002-01-0218, 2002, doi:10.4271/2002-01-0218.

[5] P. Lucio, B. Giacomo, C. P. Francesco, C. Claudio, Zeuch method-based injection rate analysis of a commonrail system operated with advanced injection strategies, Fuel 128, 2014, 188-198, doi: 10.116/j.fuel.2014.03.006

[6] S. Ishikawa, Y. Ohmori, S. Fukushima, T. Suzuki, A. Takamura, T. Kamimoto, Measurement of Rate of Multiple-Injection in CDI Diesel Engines, SAE Technical Paper 2000-01-1257, 2000, doi:10.4271/2000-011257.

[7] J. Hwang, H. Kal, M. Kim, J. Park, et al., Effect of Fuel Injection Rate on Pollutant Emissions in DI Diesel Engine, SAE Technical Paper 1999-01-0195, 1999, doi:10.4271/1999-01-0195.

[8] T. Nishimura, K. Satoh, S. Takahashi, and K. Okota, Effects of Fuel Injection Rate on Combustion and Emission in a DI Diesel Engine, SAE Technical Paper 981929, 1998, doi:10.4271/981929. 
[9] K. Tanabe, S. Kohketsu, and S. Nakayama, Effect of Fuel Injection Rate Control on Reduction of Emissions and Fuel Consumption in a Heavy Duty DI Diesel Engine, SAE Technical Paper 2005-01-0907, 2005, doi:10.4271/2005-01-0907.

[10] J. Benajes, S. Molina, D. K. Rudder, Influence of injection rate shaping on combustion and emissions for a medium duty diesel engine, J. KSME Int, Vol. 20, No. 9, pp 1436-1448, 2006, doi: 10.1007/BF02915967.

[11] P. Tinprabath, C. Hespel, S. Chanchaona, and F. Foucher, Influence of Biodiesel and Diesel Fuel Blends on the Injection Rate and Spray Injection in Non-Vaporizing Conditions, SAE Technical Paper 2013-24-0032, 2013, doi:10.4271/2013-24-0032.

[12] J. Dernotte, C. Hespel, F. Foucher, Mounaim-Rousselle C. Influence of physical fuel properties on the injection rate in a diesel injector, Fuel 96, 153-160, 2012, doi: 10.1016/j.fuel.2011.11.073

[13] S. H. Bang, C. S. Lee, Fuel injection characteristics and spray behavior of DME blended with methyl ester derived from soybean oil, Fuel, 2010,89:797-800.

[14] X. L. J. Seykens, L. M. T. Somers, and R. S. G. Baert, Modeling of common rail fuel injection system and influence of fluid properties on injection process, In: Proceedings of VAFSEP, Dublin, Ireland; July 6-9, 2004.

[15] S. Som, D. E. Longman, A. I. Ramirez, S. K. Aggarwal, A comparison of injector flow and spray characteristics of biodiesel with petro-diesel, Fuel, 2010, 89:4014-4024.

[16] J. M. Desantes, R. Payri, A. Garcia, and J. Manin, Experimental study of biodiesel blends' effects on diesel injection processes, Energy \& Fuels, 2009, 23:3227-3235.

[17] H. Dong, D. Yaozong, W. Chunhai, L. He, Zhen Huang, Experimental study on injection characteristics of fatty acid esters on a diesel engine common rail, Fuel 123, 19-25, 2014.

[18] P. Tinprabath, C. Hespel, S. Chanchaona, and F. Foucher, Influence of biodiesel and diesel fuel blends on the injection rate under cold conditions, Fuel, 144, 80-89, 2015, doi: 10.1016/j.fuel.2014.12.010

[19] J. Desantes, R. Payri, F. Salvador, and J. Gimeno, Measurements of Spray Momentum for the Study of Cavitation in Diesel Injection Nozzles, SAE Technical Paper 2003-01-0703, 2003, doi:10.4271/2003-01-0703.

[20] F. Payri, V. Bermudez, R. Payri, J. F. Salvador, The influence of cavitation on the internal flow and the spray characteristics in diesel injection nozzles, Fuel 83, 4-5, 419-431, 2004, doi: 10.1016/j.fuel.2003.09.010

[21] J. Benajes, V. J. Pastor, R. Payri, H. A. Plazas, Analysis of the Influence of Diesel Nozzle Geometry in the Injection Rate Characteristic, Journal of fluid engineering, 126, 1 2004, doi: 10.1115/1.1637636.

[22] R. Payri, J. F. Salvador, J. Gimeno, O. Venegas, Study of cavitation phenomenon using different fuels in a transparent nozzle by hydraulic characterization and visualization, Experimental thermal and fluid science, 44, 235-244, 2013, doi: 10.1016/j.expthermflusci.2012.06.013

[23] C. Badock, H. R. Wirt, A. Fath, A. Leipertz, Investigation of cavitation in real size diesel injection nozzles, Int. J. Heat and Fluid Flow, 20, 5, 538, 544, 1999, doi: 10.1016/S0142-727X(99)00043-0

[24] C. Arcoumanis, M. Baniasad, Analysis of consecutive fuel injection rate signal obtained by the Zeuch and Bosch method, SAE-Journal of Engines, 102, 3, 93021, 1993.

[25] R. Munsin, Y. Laoonual, S. Jugjai, M. Matsuki, H. Kosaka, Effect of glycerol ethoxylate as an ignition improver on injection and combustion characteristics of hydrous ethanol under CI engine condition, Energy Conversion and Management, 98, 282-289, 2015. 
[26] Soo-Young No, Application of hydrotreated vegetable oil from triglyceride based biomass to CI engine-A review, Fuel, 115, 2014, 88-96, doi: 10.1016/j.fuel.2013.07.001

[27] M. Borhanipour, P. Karin, M. Tongroon, N. Chollacoop, et al., Comparison Study on Fuel Properties of Biodiesel from Jatropha, Palm and Petroleum Based Diesel Fuel, SAE Technical Paper 2014-01-2017, 2014, doi:10.4271/2014-01-2017.

[28] K. R. Pandey, A. Rehman, M. R. Sarviya, Impact of alternative fuel properties on fuel spray behavior and atomization, Renewable and sustainable energy reviews, 16 (3) (2012) 1762-1778, doi: 10.1016/j.rser.2011.11.010

[29] M. Lapuerta, M. Villajos, J. R. Agudelo, A. I. Boehman, Key properties and blending strategies of hydrotreated vegetable oil as biofuel for diesel engines, Fuel Process Technology 2011; 92:2406-11, doi: 10.1016/j.fuel.2013.07.001

[30] L. André, M. David, S. James, The Impact of the bulk modulus of diesel fuels on fuel injection timing, Energy Fuel, 18 (6) (2004) 1877-1882.

[31] J. Heywood, Internal Combustion Engine Fundamentals, McGraw-Hill Series in Mechanical Engineering, ISBN 13: 9780071004992 . USA (1988).

[32] N. Henein, M. Lai, I. Singh, L. Zhong, et al., Characteristics of a Common Rail Diesel Injection System under Pilot and Post Injection Modes, SAE Technical Paper 2002-01-0218, 2002, doi:10.4271/2002-01-0218.

[33] F. Boudy, and P. Seers, Impact of physical properties of biodiesel on the injection process in a common-rail direct injection system, Energy conversion and Management, 50 (12) (2009) 2905-2912.

\section{ABBREVIATIONS}

K Bulk modulus of compressibility, MPa

V Volume of chamber, $\mathrm{m}^{3}$

$\Delta \mathbf{V} \quad$ Different in volume of chamber, $\mathrm{m}^{3}$

$\Delta \mathbf{P} \quad$ Different in pressure, $\mathrm{MPa}$

$\boldsymbol{\rho}_{\mathbf{f}} \quad$ Fuel density, $\mathrm{kg} / \mathrm{m}^{3}$

$\mathbf{d}_{\mathbf{m}} / \mathbf{d t} \quad$ Mass flow rate, $\mathrm{mg} / \mathrm{ms}$

$\mathbf{d P / d t}$ Rate of pressure changed in chamber, $\mathrm{MPa}$

$\mathbf{C}_{\mathbf{d}} \quad$ Discharge coefficient

$\mathbf{m}$ Theory Theoretical mass flow rate, $\mathrm{mg} / \mathrm{ms}$

A Cross section of injector, $\mathrm{mm}^{2}$

$\mathbf{N}_{\text {orifice }} \quad$ Number hole of injector

$\mathbf{R}_{\mathbf{e}} \quad$ Reynolds number

$\mathbf{V}_{\text {average }} \quad$ Flow velocity at exit of nozzle, $\mathrm{mm} / \mathrm{ms}$

$\mathbf{D}_{\text {inj }} \quad$ Diameter of nozzle, $\mathrm{mm}$

v Fuel kinematic viscosity, $\mathrm{mm}^{2} / \mathrm{s}$ 


\section{NGHIÊN CÚ̉ THÍ NGHIỆM VỀ ĐẠC TÍNH PHUN CỦA DẦU HYDROTREATED VEGETABLE OIL TRỀ ĐỘNG CƠ PHUN DÂUU ĐIỆN TỦ}

Tóm tắt. Quá trình cháy của động cơ diesel được điều khiển chủ yếu bởi quá trình phun nhiên liệu. Bắt đầu quá trình phun có ảnh hưởng lớn tới động cơ do liên quan tới lượng nhiên liệu được phun tại thời điểm phun. Bài báo này đánh giá tác động của dầu Hydrotreated Vegetable Oil (HVO) và các mẫu hoà trộn với tỷ lệ theo khối lượng là $10 \%, 20 \%, 30 \%, 50 \%, 80 \%$ của $\mathrm{HVO}$ với dầu Diesel thương mại (đã pha trộn 7\% biodiesel-B7). Nghiên cứu tập trung vào tốc độ phun nhiên liệu với sự thay đổi của áp suất phun, áp suất nền trong buồng đốt, khoảng thời gian phun. Kết quả cho thấy khoảng thời gian trễ khi phun nhiên liệu tỷ lệ nghịch với khối lượng pha trộn của HVO và áp suất phun. Với các áp suất phun khác nhau, HVO có tỷ lệ phun hơi thấp hơn so với dầu diesel dẫn đến tổng khối lượng nhiên liệu sau khi phun nhỏ hơn. Hiệu suất phun của HVO và các hỗn hợp pha trộn cao hơn dầu diesel. Với khoảng thời gian phun $0.5 \mathrm{~ms}$, độ nâng kim phun chưa mở hoàn toàn.

Từ khóa. Dầu Hydrotreated Vegetable Oil (HVO), Bulk Modulus of Compressibility, Tốc độ phun theo phương pháp Zeuch Method, Đặc tính phun, Phun dầu điện tử Common-rail

Ngày nhận bài: 10/12/2018

Ngày chấp nhận đăng: 15/04/2019 